NBER WORKING PAPER SERIES

\title{
CAN ELECTRONIC PROCUREMENT IMPROVE INFRASTRUCTURE PROVISION? EVIDENCE FROM PUBLIC WORKS IN INDIA AND INDONESIA
}

\author{
Sean Lewis-Faupel \\ Yusuf Neggers \\ Benjamin A. Olken \\ Rohini Pande \\ Working Paper 20344 \\ http://www.nber.org/papers/w20344 \\ NATIONAL BUREAU OF ECONOMIC RESEARCH \\ 1050 Massachusetts Avenue \\ Cambridge, MA 02138 \\ July 2014
}

The authors are from Wisconsin-Madison (Lewis-Faupel), MIT (Olken) and Harvard University (Neggers and Pande). We thank Maria Acevedo for superb field work and research assistance, and International Growth Center for financial support. We thank Abhijit Banerjee for many thought-provoking conversations, and thank Leila Agha, Matthew Levinson, Zejd Muhammad, and Amanda Pallais for outstanding research assistance. The views expressed herein are those of the authors and do not necessarily reflect the views of the National Bureau of Economic Research. This project received financial support from the International Growth Centre (IGC), based at the LSE and Oxford and supported by the UK DfID.

At least one co-author has disclosed a financial relationship of potential relevance for this research. Further information is available online at http://www.nber.org/papers/w20344.ack

NBER working papers are circulated for discussion and comment purposes. They have not been peerreviewed or been subject to the review by the NBER Board of Directors that accompanies official NBER publications.

(C) 2014 by Sean Lewis-Faupel, Yusuf Neggers, Benjamin A. Olken, and Rohini Pande. All rights reserved. Short sections of text, not to exceed two paragraphs, may be quoted without explicit permission provided that full credit, including $\odot$ notice, is given to the source. 
Can Electronic Procurement Improve Infrastructure Provision? Evidence From Public Works in India and Indonesia

Sean Lewis-Faupel, Yusuf Neggers, Benjamin A. Olken, and Rohini Pande

NBER Working Paper No. 20344

July 2014

JEL No. H57,O12,O53

\begin{abstract}
Poorly functioning, and often corrupt, public procurement procedures are widely faulted for the low quality of infrastructure provision in developing countries. Can electronic procurement (e-procurement), which reduces both the cost of acquiring tender information and personal interaction between bidders and procurement officials, ameliorate these problems? In this paper we develop a unique micro-dataset on public works procurement from two fast-growing economies, India and Indonesia, and use regional and time variation in the adoption of e-procurement across both countries to examine its impact. We find no evidence that e-procurement reduces prices paid by the government, but do find that it is associated with quality improvements. In India, where we observe an independent measure of construction quality, e-procurement improves the average road quality, and in Indonesia, e-procurement reduces delays in completion of public works projects. Bidding data suggests that an important channel of influence is selection -- regions with e-procurement have a broader distribution of winners, with (better) winning bidders more likely to come from outside the region where the work takes place. On net, the results suggest that e-procurement facilitates entry from higher quality contractors.
\end{abstract}

Sean Lewis-Faupel

University of Wisconsin, Madison

William H. Sewell Social Science Building 1180 Observatory Drive

Madison, WI 53706

lewisfaupel@wisc.edu

Yusuf Neggers

Kennedy School of Government Harvard University

79 JFK Street

Cambridge, MA 02138

yusuf_neggers@hks.harvard.edu
Benjamin A. Olken

Department of Economics, E17-212

MIT

77 Massachusetts Avenue

Cambridge, MA 02139

and NBER

bolken@mit.edu

Rohini Pande

Kennedy School of Government

Harvard University

79 JFK Street

Cambridge, MA 02138

and NBER

rohini_pande@harvard.edu 


\section{Introduction}

Contestable government procurement of goods and services has been estimated at over 7 percent of world GDP (OECD 2002), with the incidence rising in emerging economies: For instance, in 2007, the Indian government spent over US $\$ 21$ billion ( $\$ 18$ per capita) on the procurement of external goods and services, over double what it spent in 2000 (IMF). Yet, both the quantity and quality of recently constructed public infrastructure often remains low (Briceño-Garmendia et al. 2004). A limited supply of local qualified contractors, collusion among contractors, and corruption among public officials have each been cited as important reasons (Kenny 2007).

A number of governments have responded by adopting electronic procurement (henceforth: eprocurement) (World Bank 2007). E-procurement entails the use of electronic media, such as the internet, for some or all of the process of acquisition of goods or services. E-procurement is thought potentially to address three common concerns with manual procurement practices: lack of access to bid information, collusion among bidders, and corruption. E-procurement can increase the number of bidders by lowering the costs of obtaining information about a tender process, thus increasing the number of firms who can bid. Likewise, e-procurement can reduce collusion among bidders by providing information about tenders to firms outside a local cartel, allowing non-cartel firms to participate and breaking up local bidding cartels. E-procurement can also potentially mitigate corruption by reducing the degree to which government officials selectively withhold information or refuse to take bids from non-favored bidders. Moreover, by ensuring public access to all procurement data, e-procurement enhances transparency and the possibility of public oversight.

However, it is also plausible that in low income settings, where information technology coverage and other aspects of state capacity remain low, e-procurement can only effect limited change and can potentially make things worse. Potential contractors (who are currently not in the system) may continue never to learn about available tenders, and cartels and corrupt officials may continue to use strong-arm tactics to prevent entry by such contractors. If many small firms have limited access to the internet, requiring electronic bids could actually harm competition.

In this paper we examine the impact of electronic procurement on public works projects in two large emerging economies: India and Indonesia. In India, we examine procurement practices between 2000 and 2009 for a federally funded rural road construction program which is implemented 
by state road departments, the Pradhan Mantri Gram Sarak Yojana (PMGSY) program. Under this program, roughly 145 road packages are tendered per state per year. In Indonesia, we examine contract data from the national Ministry of Public Works for both construction and consulting (e.g., engineering management and design) contracts each year. On average, 32 consultancy and 58 construction packages per province were issued each year. Our evaluation exploits the fact that in both countries e-procurement was gradually rolled out at the state (India) or province (Indonesia) level. This allows for a difference-in-difference strategy: We compare outcomes in states/provinces before and after the adoption of e-procurement, as well as in those continuing under manual procurement practices, allowing us to quantify the benefits or costs of the practice in both countries.

For both countries, we obtained administrative data on the complete universe of contracts from before and after e-procurement by scraping publicly available information from respective government websites. In Indonesia we have bidding and final contract data for all tenders; in India, the website publishes final contract data but not the details on individual bids. All told, this leaves us with a dataset of over 20,000 contracts in India and over 14,000 tenders in Indonesia. In addition, in India, we hand collected bidding data on tenders for four states which we use to supplement the administrative data.

We first show that, in both India and Indonesia, e-procurement increases the probability that the winning bidder comes from outside the region where the contract takes place. This is consistent with e-procurement decreasing the costs of submitting bids for those not physically present. We next examine the impact on the ultimate outcomes of interest: price, quality, and timeliness. We find no systematic evidence that electronic procurement lowers prices paid by the government. In Indonesia, the point estimates are consistent with small (2-5 percent) reductions in prices, but these are not statistically significant. In India, final prices are unaffected. Overall, we can statistically rule out (at the 5 percent level) declines in contract values of more than 2.7 percent in India, of more than 6.6 percent for Indonesian consulting projects, and of more than 14.1 percent for Indonesian works contracts.

In contrast, e-procurement led to quality improvements albeit along different dimensions in the two countries. A first measure of quality is time-overrun in project completion. Reports of corruption of procurement in India typically focus on cases where works are abandoned halfway 
through or completed in a very tardy manner. In our data we see that 77 percent of road projects in India and around 95 percent of public works projects in Indonesia are completed late. In India, we observe no statistically significant changes in late works, while in Indonesia these declines are large and significant - whereas only 5 percent of conventionally procured construction projects in Indonesia are completed on schedule, 20 percent of electronically procured construction projects are on time.

A separate indicator of quality, only available for India, is an independent audit report on construction quality, which was conducted identically in roads completed under both e-procurement and traditional procurement. According to this measure, we find that e-procurement leads to higher quality roads, with the quality grades rising by about 12 percent in e-procurement projects compared to other projects.

We then explore the degree to which the results are driven by improving outcomes among already winning bidders, as opposed to changing who wins. To see whether the changes in outcomes we observe are driven by changes in selection of who wins, for the key variables of interest - price, delays, and quality - we estimate a fixed effect for each contractor and examine how the average quality characteristics of winning contractors (i.e., the fixed effects of who wins) change with eprocurement. We find that after e-procurement, winning contractors in India tend to be those who have higher quality on average. In Indonesia, we find evidence that those contractors who win after e-procurement are systematically less likely to be late. This suggests that a key mechanism for e-procurement is allowing higher quality contractors to enter and win projects, rather than simply encouraging better performance from an existing set of contractors. Increased entry of contractors could reflect better information flows and/or reduced ability of local contractors to prevent others from filing tenders.

This paper is related to several economic literatures. In the corruption literature, a number of recent papers use procurement data to examine corruption (Di Tella and Shargrodsky 2003, Ferraz and Finan 2008, Bobonis, Fuertes, and Schwabe 2010, Bandeira, Prat, and Villetti 2009). While there is also a growing economics literature on procurement (Bandiera et al. 2009, Krasnokutsaya and Seim 2006), much of the literature has focused on the rules governing the auction (i.e., scoring auctions vs. lowest-price auctions, etc.) (Tran 2008). This paper suggests that an important component, at least for ensuring quality, can be in the implementation of the procurement auction, 
holding the rules fixed.

Second, this paper is part of a recent, broader agenda that documents the role of communication technology in development. While there are several studies that document the impact of cell phone technology on market access (Jensen 2007, Aker 2010) and education (Aker et al. 2012), this paper represents one of the first studies to examine the impact of the internet on governance issues.

One advantage of our approach is that we use the same methodology to study separate eprocurement programs, in two different countries. To the extent that the findings from both countries are similar, the external validity of our results is given credence. To the best of our knowledge, this study represents one of the first microeconomic studies that uses differences-indifferences to simultaneously evaluate a new program in multiple countries, allowing for more careful conclusions with respect to external validity. ${ }^{1}$

The paper is structured as follows: In Section II we describe the institutional details relating to procurement practices and road construction in India and Indonesia. In Section III we describe the data and empirical strategy. In IV we report the findings. Section V concludes.

\section{Background}

We start by describing the public works programs in our two study countries, followed by the nature of e-procurement adopted in these two settings. We conclude the section with a brief description of likely channels of influence of e-procurement.

\section{A India}

\section{A.1 Public Works Program and Manual Procurement}

In the year 2000, India launched a large-scale rural road construction scheme called Pradhan Mantri Gram Sarak Yojana (PMGSY). The federal government provides funding for this scheme, but full executional responsibility lies with state governments. While implementation of this program is coordinated at a national level, each state has an independent rural roads department which decides the schedule for road construction and manages procurement. PMGSY roads follow a uniform

\footnotetext{
${ }^{1}$ The other study of this nature we are aware of is Gruber and Mullainathan (2005), which evaluates the impact of state and provincial cigarette tax changes in the US and Canada.
} 
criteria for road construction in terms of material usage and quality for all Indian states.

For PMGSY, all states use the same procurement rules and standardized bidding document, provided by the national roads agency. The procurement process for PMGSY roads is a cost-based auction procedure. Specifically, conditional on meeting a pre-specified set of technical qualifications intended to ensure a contractor is capable of completing the project, the contract is awarded to the lowest bidder. Importantly, these rules are identical with and without electronic procurement.

Anecdotally, public procurement in India is rife with corruption, and claims of impropriety exist throughout the contracting process. Contractors have reported being physically intimidated or barred from submitting bidding documents. The handling of bidding documents after submission has also been called into question with claims of altered bids, inspection of bids prior to technical reviews, and intentional loss of submissions. There is also concern that technical qualifications are used to unreasonably exclude certain firms from the bidding process. The implication of many of these reports is that government officials collect rents in exchange for some advantage in the bidding process.

As a case study, we examined the tendering process for manual procurement for a random sample of 190 road contracts issued between 2001 and 2006 in the Indian state of Uttar Pradesh. As Figure 1 shows, there is very little competition in PMGSY contracts. In 95 percent of cases, the price bid of only one firm was evaluated; that is, there was only one bid submitted or all other bids were disqualified based on technical requirements. When we observe multiple bids here, over three quarters of the time all but one bid are disqualified. In the case of any technical disqualification, all but one bidder are disqualified 100 percent of the time. Prima facie this pattern of disqualifications is consistent with corrupt officials enforcing a desired winner.

In 2000, when the program began, all Indian states used a manual paper-based procurement system to bid out contracts to private contractors. This process involved obtaining internal approval of the project, publishing a Notice Inviting Tenders (NIT) in several media outlets (typically newspapers), having suppliers obtain detailed bid preparation materials from the government, receiving bid submissions by suppliers, receiving bid evaluations by buyers, and finally, the awarding of the procurement order and signing of agreements. The complete process required a long chain of internal authorizations (at times involving several departments), several visits by suppliers to departments, and the generation of reams of paper-based statements and evaluations. 
The Indian IT Act of 2000 provided legal recognition to electronic transactions. Since then, several Indian states have passed legislation enacting e-procurement, and the rural roads department in several states followed by adopting e-procurement practices for road construction. We exploit this variation across time and states for our empirical analysis. Our sample covers 27 Indian states and territories during the period January 2000 through August 2009. During this timeframe, 9 states adopted a system of electronic procurement. Figure 2a shows the dates when e-procurement rules were adopted in various states through August 2009. The first state to adopt, in 2004, was Andhra Pradesh, which (along with Karnataka) is one of the technological leaders of India. (Note that in some states (Chattisgarh, Gujarat, and Orissa), contracts which are below a state-specified cost threshold do not go through the electronic procurement process and are processed on paper. Since the threshold may respond endogenously to the auction policy (see, e.g., Tran 2008), during the applicable periods, we classify all projects as electronically tendered in these states.)

\section{A.2 Public Works Program and Procurement}

In Indonesia, we examine the national Ministry of Public Works (MPW). The MPW procurement process covers mainly two types of contracts, works and consulting. Works contracts refer to projects such as the building or repairing of roads and bridges, where physical services or construction work are conducted by the contract winner. Access to heavy equipment and various construction materials is therefore typically a necessary component for these projects. Consulting contracts, in contrast, entail the provision of professional expertise by the winning bidder in planning or supervision services such as design and management. Depending on the project, procurement takes place either at the national headquarters in Jakarta or at the provincial offices of the MPW.

Works and consulting contracts additionally differ in the structure of their bidding processes. Works contracts are generally assigned to the low bidder conditional on meeting minimum administrative and technical qualifications, as in India. Consulting contracts involve a pre-qualification phase in which potential bidders first submit a document containing administrative, financial, and work experience information. A shortlist of firms meeting minimum qualification requirements are then invited to submit technical and cost bids. The winning bidder is assigned using a formula based on a combination of technical score and price, rather than simply lowest bid conditional on 
meeting minimum technical requirements as with works projects. For both types of contracts, a minimum of three bid submissions are required, otherwise the processes are repeated. The overall pool of bidding firms consists of both private firms and state-owned construction firms, with state-owned firms competing against the private sector without any special preferences.

Public procurement is generally understood to be "one of the most corruption-ridden sectors" (Freedom House 2012) in Indonesia. For example, the 2009 Enterprise Survey of Indonesia (World Bank and IFC) sampled 1,444 firms comprising a representative sample of the non-agricultural formal private economy in the country. In the survey, 38.1 percent of respondents who had attempted to secure a government contract in the previous year indicated that firms with characteristics similar to theirs make informal payments or give gifts to public officials to secure such contracts, though the average value given for these bribes was only 1.8 percent of the total contract value. A separate survey of 792 randomly sampled construction, consulting, and supplier firms conducted in 2010 by the Indonesia Procurement Watch (Indonesia Procurement Watch 2011 ) provides further suggestive evidence of corruption in the government procurement process, with 92.7 percent of respondents answering that they thought their firm had ever given bribes to the government officials

involved in managing procurement. Additionally, 97.3 percent of respondents believed that it was not possible to win the contract tender without bribery and more than 95 percent indicated that the typical value of a bribe was more than 10 percent of the contract value. Beyond survey results, of the 196 cases considered by the Corruption Eradication Commission (KPK) of the Government of Indonesia between 2004 and 2010, 86 dealt with bribery and graft related to the procurement of goods and services and every such case resulted in a conviction (Onishi 2009, Parlina 2011).

Anecdotal evidence suggests that the manual procurement process contributes to the corruption problem in much the same ways as discussed in India. For example, government officials may not make the detailed documents required to prepare a bid available to non-favored firms or purposely misinform them about the proper submission process (UNAFEI 2008). Alternatively, there could be physical intimidation of firms that are not part of the cartel from submitting bids.

\section{A.3 E-Procurement}

Indonesia began rolling out a "semi-electronic procurement" (SEP) system in 2004 in the central ministry in Jakarta and expanded the procedure across the 33 provincial offices in approximately 
concentric circles from Jakarta over the next 5 years, as shown in Figure $2 \mathrm{~b}$. Under SEP, firms are able online to register expressions of interest, to download detailed bidding and technical qualification documents, to submit pre-qualification materials, and to post questions and complaints. However, due to a regulatory constraint, the final submission of bids was still required to be conducted manually (hence the term "semi") throughout the period we study. The SEP process thus covers the entire procurement process except the final submission of bids. There was no change in procurement rules associated with the switch to SEP; procurement still followed the Presidential guidelines for the procurement of government goods and services issued in 2003 (Government of Indonesia, 2003). ${ }^{2}$

Prior to the adoption of SEP in a province, procurement was in a "copy to internet" (CTI) phase where the acquisition of bidding and technical qualification documents and the submission of bids were carried out manually, but the contract details (bids of each firm and the winner) were posted to the internet ex-post to be publicly available. Crucially for our analysis, the data made public during the copy-to-internet and semi e-procurement systems are identical and in fact use the same electronic platform; the only difference is that procurement actually takes place electronically on the SEP system, whereas in copy-to-internet, information is just released publicly ex-post. We discuss the data in more detail below.

\section{B E-procurement: Channels of Influence}

The price and quality effects of the adoption of e-procurement are ex-ante theoretically ambiguous. We outline several potential channels of influence below.

\section{Benchmark: Efficient corruption where quality matters.}

For a given price/quality tradeoff, the most efficient firm (in terms of the ratio of the quality delivered to price received) is able to pay the highest bribes. Corruption should therefore lead to higher prices paid by the government to cover additional bribes to government officials but not necessarily a reduction in quality, since the most efficient firm still wins. If e-procurement reduces the ability of corrupt officials to allocate a contract to a given firm, then a reduction in prices should be observed, but quality and the identity of the winning firm should not be affected.

For example, in several different contexts, from Asian procurement of electrical equipment

\footnotetext{
${ }^{2}$ Full e-procurement was not introduced until after the period under study.
} 
(Tran 2008) to stamp auctions in New York (Asker 2010), economists have noted that such preauctions exist. In the case of electrical equipment, the secret pre-auction identified the bidder who could supply the specified equipment at the lowest cost and who could hence offer the highest combination of bribe to the corrupt official at the lowest price to the government; the corrupt official subsequently arranged with other cartel members to ensure that the firm so identified would win. If such an environment was operating here, eliminating corruption would not change the identity of the winning bidder or their ability to deliver a high quality road; instead, the firm with the largest surplus should still win, but the prices paid by the government should fall since they are no longer inflated to provide rents to the corrupt official.

\section{Alternative 1: Inefficient corruption on the quality dimension when lowest price} always wins.

Suppose that corruption means that the procurement officer has connections with certain firms. After seeing bids, he uses private personal connections to firms to choose one bidder and then allows that firm to resubmit at just under the equilibrium price. Rules require that the winning bidder must submit the lowest price, but the firm can then extract rents by providing low quality works, not finishing the work, and/or charging for extra costs later. In this environment corruption leads to low quality (delayed work or poor construction) and potentially higher prices. If e-procurement compels procurement officials to follow the rules and such resubmission is no longer possible, then this mechanism can be eliminated-firms need to compete on costs and quality. This can lead to average quality improvements and/or lower prices.

\section{Alternative 2: Non-corrupt inefficiency.}

Even in the absence of corruption, e-procurement may yield improvements in quality and prices. In a setting of onerous regulations and shirking on the part of procurement officials (who need not be engaging in illegal activity to increase their own rents but rather may be hindered by overly complicated procurement rules or exert less than full effort while behaving legally), e-procurement may streamline the procurement process and increase the observability of government officials. This in turn can lead to the exertion of more effort and to greater returns for a given level of effort, potentially improving quality and price outcomes. Also, in an environment of limited bidder information, where it is difficult for firms to determine the full set of contracts available for bidding or to obtain the bidding materials in person, e-procurement may reduce these costs and increase 
the pool of firms bidding on projects. The associated increase in competition may then improve quality or lower costs. Bandiera et al. (2009) document such practices in the context of Italy.

\section{Data and Empirical Strategy}

In this section we describe the Indian and Indonesian datasets, followed by our empirical strategy.

\section{A Data}

\section{A.1 India}

We obtain administrative data on costs, quality, and delays associated with each PMGSY contract issued between January 2000 and August 2009 from multiple PMGSY websites. The dataset covers 27 Indian states. For PMGSY, some road packages are split into multiple tenders, each with its own contract covering a subset of roads in the package. As a result, our final dataset covers (at least partial information for) 30,578 packages and 35,610 associated contracts.

A first set of outcomes are the cost outcomes associated with each contract. The estimated cost is the amount budgeted by the national authority for construction of a specific road or set of roads in a package. A contract or payment above this amount can only occur with permission from the national offices. The contract value is the amount the government agrees to pay the winning firm for the relevant work. The final payment records the total amount paid out for each package, which as discussed above, may be distributed among multiple contracts and includes any amendments to the contract that occur during construction.

We have measures of both timeliness and actual project quality. For timeliness, we track the time to execution. We use "late completion," which is an indicator variable taking value one if road construction work is not completed by the date agreed to in the initial contract. We also construct a continuous "time overrun ratio" variable, which is the ratio of actual to agreed upon time to completion.

To measure the quality of project implementation, we use quality reports submitted by the National Quality Monitors. During construction, PMGSY has a multi-tier quality monitoring system, with local, state, and national monitoring. National monitoring is conducted by National

Quality Monitors (NQM), who are retired engineers from other states. The assignment of package 
to NQM is randomized and is therefore conducted similarly in places with and without electronic procurement. ${ }^{3}$ Since it is randomized and thus uniform across locations, we focus on the outcomes of this national monitoring (NQM) as our quality outcome. NQMs evaluate each part of the work for material and workmanship as per the format of the standardized "NQM Inspection Report," indicating the tests carried out and the test results obtained. Overall grading includes management issues, contract management, and quality of work. We use a binary assessment (satisfactory/unsatisfactory) of the technical fitness of the road at the time of inspection.

For a subset of packages in the states of Andhra Pradesh, Chhattisgarh, Karnataka, and Uttar Pradesh, we have bidding data. This includes the total number of bids submitted in each auction. Before submitted bids are unsealed, engineers in each state decide which firms have the technical ability (in training, equipment, and experience) to complete the project based on materials firms submit with their bid. We also observe how many of the submitted bids in each auction are judged to be from technically qualified firms.

\section{A.2 Indonesia}

We scraped data from the CTI and SEP websites of the Indonesian Ministry of Public Works, capturing the complete universe of procurement from 2004 through 2008. Over 14,000 contracts from the MPW national headquarters and the 33 provincial offices are covered. Each entry in the data is at the contract level and specifies the estimated cost, which is, as in India, the maximum amount allowed by the MPW to be paid for a given contract. Limited information on type of project is available, as are all bidder names, bid amounts, disqualifications, and final contract values.

We also have the dates on which the notice and details for each contract were first posted online (and concurrently in traditional media), as well as the dates of bid opening and contract award. For road projects (which represent a subset of all projects covered by the Ministry of Public Works), we have a separate database from the road division that tracks the start dates and expected and actual completion dates for the services associated with each contract. As with India, we construct "late completion" and "time overrun" variables. No direct quality measure is available for Indonesia.

\footnotetext{
${ }^{3}$ The NQMs are given the letter of request once every two months for carrying out inspection for the forthcoming two months. The NQMs are required to inspect three districts in a single visit in one state in each of the two months. The letter of request allocates a mix of works in progress and completed works. The letter indicates the specific location of works to be inspected and which are in-progress or completed works. Within a block (the administrative unit below district), projects to be inspected are chosen on a random basis.
} 
For regressions which consider as an outcome variable the above measures of the timeliness of completion, the number of firms expressing interest, or the number of firms bidding, we trim the top and bottom 1 percent of sample observations.

\section{B Descriptive Statistics}

In the first column of Table 1, we present a set of basic descriptive statistics for the Indian data, and in the remaining columns we present statistics from Indonesia. All monetary variables are in logs, which is the form in which they will be used in the regressions below.

Examining the Indian data, in an average year, the typical state sanctioned almost 145 packages worth $9.61 \log$ lakh rupees (US\$33+ million at exchange rates for 2005, the midpoint of our dataset; 1 lakh is 100,000 rupees) covering over $6.74 \log$ kilometers (525 miles) of road. At the package level, the average log estimated cost of completion over the period observed is 5.211 log lakh rupees, or about US $\$ 416,000$ in 2005. In the subset of auctions for which we have data (as discussed above, these are from 4 states), there are an average of 2.7 total bids and 1.7 qualified bids.

One contract per package is the mode but a long right tail is observed. On average, a package is associated with 1.25 contracts for which we have data. Roads contracts generally come in below estimated cost (most likely because exceeding estimated cost requires an additional bureaucratic process). However, cost overruns with respect to the contracted price appear to be relatively common post-contracting. The average payment on completed projects exceeds the average contract value by about 46 percent.

Turning to delays and quality, completion before the contracted due date was rare, with more than three quarters of contracts finished after the assigned deadline and an average delay of 244 days. There was heterogeneity in quality, with 72 percent percent of projects receiving a satisfactory quality rating on first inspection.

Examining the Indonesian data in Table 1, between 2004 and 2008 the average Indonesian province auctioned about 88 contracts per year, with nearly twice as many works as consulting projects, for a province-level average log total budget of $25.67 \mathrm{log}$ rupiah (approximately US\$12million at 2006 exchange rates). This implies that the total annual budget for all contracts in our data averages $29.61 \log$ rupiah (roughly US\$615+ million). At the project level, the average log estimated cost for works projects is 20.95 log rupiah (about US\$106,000) and for consulting 
projects is $19.78 \log$ rupiah (roughly US\$33,000). The final contract value for a given project is on average 10 percent lower than the official estimated cost provided by the government prior to bidding. Firms winning contracts are typically based in the same province as the contract, more than 80 percent so for works projects. As with the data from India, delays are common; nearly all works projects (95 percent) and more than half of consulting projects (55 percent) are completed later than the initially agreed upon date.

\section{Empirical Strategy}

We estimate impacts separately for India and Indonesia. In both cases, we make use of a differencein-difference strategy, but our implementation differs slightly across countries, as described below.

In India, for road package or contract $i$ in state $s$ which began in year $t$ we estimate the following OLS specification:

$$
y_{i s t}=\alpha_{s}+\beta_{t}+\mu E P R O C_{s t}+X_{i s t}^{\prime} \gamma+\epsilon_{i s t}
$$

where $i$ is a package or contract, $s$ is a state, and $t$ is a year, and $E P R O C_{s t}$ is a dummy for e-procurement adoption by state $s$ as of year $t$. Controls $X_{i s t}$ are log estimated cost and log road length. All regressions include state $\left(\alpha_{s}\right)$ and year $\left(\beta_{t}\right)$ fixed effects. In some cases we collapse the package-level data to the state level and estimate regressions using annual state-level data. In all cases we cluster standard errors by state.

In Indonesia, the availability of e-procurement at the province level does not necessarily imply that all projects within a province will be contracted using the system. ${ }^{4}$ To obtain the average impacts of the use of e-procurement, we instrument for actual e-procurement use with the adoption of e-procurement in the province, as follows. The regression of interest (i.e. the second stage) is:

$$
y_{i s t}=\alpha_{s}+\beta_{t}+\theta E P R O C P A C K A G E_{i s t}+\delta X_{i s t}+\epsilon_{i s t}
$$

where $E P R O C P A C K A G E_{i s t}$ is a dummy for e-procurement use in project $i$ in province $s$ as of year $t$. The project level e-procurement variable EPROCPACKAGE $E_{i s t}$ is instrumented with $E P R O C_{s t}$, which is a dummy for whether e-procurement has been adopted by province $s$ as of

\footnotetext{
${ }^{4}$ It is possible that this is true for India as well, but for India we do not observe what fraction of packages actually used e-procurement in a given year.
} 
time $t .^{5}$ The control variable $X_{i s t}$ is the log estimated cost (since we have many different types of projects and there is no metric available in the data other than estimated cost, we cannot control for road length as for India). Standard errors are clustered by province.

In our regression tables we typically report results for the India sample as Panel A. In Panel B we report results for Indonesia works projects and in Panel C for Indonesia consulting projects.

\section{Identification Check}

An important potential concern with our empirical strategy is that, since the adoption of eprocurement is not randomly assigned, we need to ensure that the timing of e-procurement adoption is not correlated with differential trends in procurement that would have occurred in the absence of e-procurement.

To examine this, we begin by checking whether, overall, the adoption of e-procurement is associated with a change in the volume (total budget for procurement) or structure (i.e., across how many contracts procurement is distributed) in a given state or province. Column (1) of Table 2 reports regressions where the dependent variable is log total estimated cost at the state-year level and the explanatory variable of interest is an indicator for any contract being awarded under eprocurement, with log of road length included as a control for India. Column (2) repeats the exercise using number of projects as the dependent variable, controlling for log total state-year estimated project cost. In neither country do we see a significant impact of e-procurement adoption on the total budget allocations (column 1) or the number of projects they are broken into (column 2) at the state/province-level, suggesting that e-procurement was not coincident with major changes in the amount or structure of contracts being procured.

Second, we examine whether the year of official adoption of e-procurement at the state level (conditional on e-procurement occurring after the first two years in our data - that is, after 2005 in Indonesia or after 2001 in India) is significantly related to the difference in log average contract value between the first two years of the data (i.e., between 2001 and 2000 for India (Appendix Table 1, Panel A) and between 2005 and 2004 for Indonesia (Appendix Table 1, Panels B and C). This regression looks at whether differential initial trends predict the year of subsequent e-procurement

\footnotetext{
${ }^{5}$ The first-stage coefficient and F-statistic for works projects are, respectively, 0.359 and 40.79 and for consultancy projects are 0.491 and 78.11 .
} 
adoption. We see no correlation between change in state-level contract value and the timing of e-procurement for either India or Indonesia.

\section{Results}

\section{A Did E-procurement Change the Contracting Process?}

\section{A.1 Contracting Execution}

In Table 3 we first examine whether the introduction of e-procurement has an impact on the duration of the project contracting phase. In columns (1) and (2) we consider the time elapsed between tender notice and contract award and between bid opening and contract award. Both variables are available only for the Indonesia sample. While neither variable is significantly impacted for works projects, we find an increase of 54.13 days (statistically significant at the 1 percent\% level), a more than 50 percent increase, in the time elapsed between the tender notice and awarding of contract for consulting projects. In conjunction with the absence of an effect in column (2) on the amount of time between bid opening and award, this implies that the period of time between the tender notice and the opening of bidding, in which firms can learn about potential contracts and prepare their bid documents, becomes significantly longer for consulting projects with the use of e-procurement.

\section{A.2 Who Bids and Who Wins?}

We next consider indicators of changing contractor identity. In column (3) of Table 3 we investigate the impact of e-procurement on the number of firms who fill out the initial form expressing an interest in bidding. These data are only available for Indonesia. For nearly every works project, this process entails registering to be allowed to participate in bid submission and download the detailed bid documents. For all consulting projects and a small subset of works projects, expression of interest involves the submission of a pre-qualification document on which firms are scored and a subset of those passing are chosen to submit bids. We observe a significant more than doubling in the number of firms expressing interest in the case of works projects.

In column (4) we examine the number of firms actually submitting a complete bid. This number 
is relatively low in India with the average manual procurement contract receiving roughly 2.9 bids. This number is higher for Indonesia at over 7 bids per works project and 3.2 per consulting project. However, in no instance do we see a significant increase in the average number of bids.

Column (5) examines whether e-procurement changes the likelihood that the winning firm is based in the same area in which a project is tendered. While home province is officially registered in Indonesia, we proxy for firm default location in India with the district where we first observe the contractor in the data in the pre-e-procurement period. ${ }^{6}$ In general, as with most construction projects, where moving equipment is quite costly and where there is often a need for local sources of materials (e.g., hot asphalt), there is a strong tendency to be local: Nearly 60 percent of winning bids come from firms located in the same district in India and over 80 percent of works contracts are in the same province in Indonesia as where the contract is to be executed.

We observe a significant 11 percentage point decline in this variable in India and a 23 percentage point decline for consultancy projects in Indonesia. Given that it is much easier to move engineers geographically than to move heavy equipment and asphalt plants, it is not surprising that the impacts for Indonesia - where cross-provincial distances are much greater than the cross-district distances we observe in India - are concentrated among consulting projects.

Finally, we examine in column (6) whether e-procurement changed entry of new firms. Specifically, we examine whether the winning bidder was present and won a contract bid in the first year of our data (2000 or 2001 for districts in India or 2004 for provinces in Indonesia). This regression is restricted to observations which fall in years subsequent to these initial years. We observe a highly significant increase of 41 percentage points for consultancy projects in Indonesia, showing that e-procurement leads to more contracts being won by pre-existing winning firms. Combined with column (5), this suggests that e-procurement leads to projects being won by pre-existing firms from other provinces.

One consistent explanation for these findings is that e-procurement improves access to information for firms outside the area where procurement is taking place. This is a relatively larger benefit for firms that are farther away and may also favor pre-existing firms with a documented record of success.

\footnotetext{
${ }^{6}$ Note that this variable is only defined for firms we can match to a firm that we observe in the first year of the data.
} 


\section{B Did E-Procurement Change Procurement Outcomes?}

There are three main outcome variables about which the government cares when procuring for the provision of a service/construction of a project: the price it pays for the contract, the timeliness with which the contract is executed, and the quality of work undertaken. In this section we examine the impact of e-procurement on each of these three dimensions.

\section{B.1 Prices}

To examine the impact on prices paid, we first consider impacts in each country on the contract value agreed upon between the winning bidder and the government. Column (1) shows no statistically significant impact in India on log contract value, conditional on the log length of the road and the $\log$ estimated cost of the road. The point estimates are quite small $-0.02-$ and the 95 percent confidence interval ranges from -0.027 to 0.064 . This means that we can reject the hypothesis that there was more than 3 percent cost savings associated with e-procurement, based on the original contract value. For Indonesia, conditional on the log estimated cost, for both works and consultancy projects, the point estimates suggest a small reduction in log contract value, though it is not statistically significant. The confidence intervals suggest that, at 95 percent confidence, we can rule out price declines in Indonesia of more than 14.1 percent for works projects and of more than 6.6 percent for consulting projects.

Of course, the government does not care about the contract value, per se; rather, the more important measure is the actual amount paid to the contractor. Cost overruns are frequent, so as discussed above, the amount paid is typically higher than the contract value. Column (2) examines the impact on the final amount actually paid by the government, including any overruns or contract amendments. Values for this variable are only available for India. Note that the observation count falls substantially here since not all packages were complete at the time of data collection $^{7}$. Again, no significant impact is observed. The point estimate for India is a 2.5 percent drop in final payments, with the 95 percent confidence interval ranging from a 8.7 percent decrease to a 3.7 percent increase. Given the uncertainly around this point estimate and that of the effect on contract values, we are not able to infer whether changes in final payments, if any, came through

\footnotetext{
${ }^{7}$ As we show subsequently, the date to completion is unaffected by e-procurement, so this sample selection is unlikely to be an issue.
} 
shifts in contract values or changes in cost overruns. On net, the evidence in this section suggests that there was no statistically detectable impact on prices paid for projects, and to the extent there are effects we cannot detect, they are not overwhelming in size.

\section{B.2 Project Timeliness}

We next examine delays in the execution of projects. In column (3) of Table 4 we consider late completion - a dummy taking value 1 if a project is finished after the contracted completion date and 0 otherwise. Late completion is very common in both countries. More than three quarters of projects in India are completed late, while 95 percent of works projects and more than half of consultancy projects in Indonesia are not finished on time. In the case of Indonesian works projects, we see a significant 16 percentage point decline in this variable associated with the adoption of eprocurement. We then consider the time overrun ratio in column (4). This is the actual time to completion divided by the contracted time to completion. For both India and Indonesian works projects, we observe high levels of overrun - on average, actual time to completion is double the contracted time. However, in neither country do we see a significant decline associated with adoption of e-procurement. ${ }^{8}$

\section{B.3 Quality}

In the final four columns of Table 4, we turn to package-level quality measures from a nation-wide auditing process. As described above, these data only exist for the India sample. The Indian National Quality Monitoring process is coordinated centrally, and inspectors audit a randomly selected bundle of roads (both in progress and complete). Specifically, for auditing roads in a given season, the national monitor is told how many of each type of project (complete and ongoing) to sample and from which districts in a state. He then separately samples at random from the lists of projects provided by the state road department. In addition, inspectors are allocated follow-up audits for roads, and here, poorly graded roads are oversampled.

Thus, only the first quality grade is randomly selected. We examine two variables: the first

\footnotetext{
${ }^{8}$ Note that for Indonesian works, the point estimate on the time over-run ratio is positive while the dummy on late completion is negative. This is due to a few extreme outliers. If we trim the bottom and top 2.5 percent of observations, the coefficient and statistical significance in column (3) are essentially unchanged, but the point estimate in column (4) becomes -0.025, not statistically significant.
} 
quality grade and the minimal quality grade for the road project given by the national monitor. The minimum quality grade is the lowest quality grade given during any of the inspector evaluations across all contracts in the package. The quality score is measured as either 0 (unsatisfactory) or 1 (satisfactory). We separately consider quality outcomes for all projects (including those in progress) and for only completed roads .

In columns (6) and (8), we find highly significant impacts on both the first and minimum quality grades for completed roads. E-procurement is associated with increases of 12.3 and 19.4 percentage points in the first quality grade and worst quality grade, respectively. In contrast, we do not see any significant impacts on incomplete works (columns (5) and (7)). The evaluation of incomplete projects may be inherently prone to greater measurement error because a project is behind schedule, being revised, or is simply not far along enough to be accurately judged. We see no evidence in the data that e-procurement leads to more abandoned (never completed) contracts or to a differential number of incomplete projects at the time of inspection, suggesting that the difference in significance of the quality estimates cannot be explained by e-procurement driving low-quality contracts to an even lower level that results in unfinished construction.

\section{Selecting Better Contractors, or Making Existing Contractors Better?}

We observe significant impacts of e-procurement on road quality in India and evidence of reductions in delays in Indonesia. We also find that winning contractors are more likely to come from outside areas. We now explore a potential channel of influence: whether e-procurement changed the pool of contractors who bid and caused better contractors to be selected.

To the extent that e-procurement improves outcomes, an important question is whether it does so by selecting better contractors, or by encouraging existing contractors to perform better. Selection effects would occur if the main effects described above were primarily driven by e-procurement spurring new entrants, and if those new entrants won; treatment effects on existing contractors could occur if increased competition or lower corruption led these incumbent firms to submit higher quality bids.

To investigate these possibilities, we conduct a two-stage strategy where we first estimate a fixed effect for each firm in the data. This measures each firm's average quality. We then examine whether e-procurement leads to the selection of firms with higher average quality. If it does - and if 
these coefficients match the overall effects documented above - we can then conclude that selection effects are playing a large role. On the other hand, if e-procurement does not lead to changes in average firm quality, then the quality and delay effects documented above must be arising through increased performance from a given set of incumbent firms.

For each outcome of interest $y$, we initially estimate the following regression:

$$
y_{i c s t}=\tau_{c}+\alpha_{t}+\alpha_{s}+\delta E P R O C_{s t}+X_{i s t}^{\prime} \gamma+\epsilon_{i s t}
$$

where $\tau_{c}$ is a winning contractor fixed effect and $E P R O C_{s t}$ is a dummy for e-procurement adoption in state $s$ as of year $t .{ }^{9}$ We include state/province and year fixed effects and controls as before. We generate a full set of contractor fixed effects from this regression and then use them as the outcome variable in the following regression:

$$
\tau_{\text {cist }}=\alpha_{t}+\alpha_{s}+\beta E P R O C_{s t}+X_{i s t}^{\prime} \gamma+\epsilon_{i s t}
$$

where $\tau_{\text {cist }}$ is the estimated $\tau_{c}$ from the initial regression for the contractor that won project $i s t$. The estimation is weighted by the inverse variance of $\tau_{c}$ (as estimated from the first stage). This regression asks how e-procurement affected the choice of which contractors won a given package. ${ }^{10}$

Examining prices in columns (1) and (2) of Table 5, we find no evidence suggesting that the introduction of e-procurement was accompanied in either India or Indonesia with the selection of winning firms that tend to make lower or higher winning bid amounts for a given estimated cost .

We then examine delays. In column (3), we see that for works projects in Indonesia, eprocurement was associated with firms that tended to be less late being more likely to win. The magnitude of the coefficient - 0.058 - is about one-third of the equivalent magnitude in column (3) of Table $4-0.161$ - which suggests that one-third of the effect is driven by changes in selection, while two-thirds of the effect is driven by existing contractors performing better.

We also find substantial impacts on the average quality of contractors, as shown in columns (6) and (8). The magnitudes of these coefficients are between fifty and eighty percent of those for the

\footnotetext{
${ }^{9}$ For Indonesia, we additionally include the dummy variable,EPROCPACKAGE $E_{i s t}$, to account for the fact that e-procurement adoption at the state level does not imply that all projects in that province will be tendered using e-procurement.

${ }^{10}$ For Indonesia as before, we use EPROCPACKAGE $E_{i s t}$ instrumented with $E P R O C_{s t}$ in this regression.
} 
overall quality effects in Table 4 . This suggests that the quality effect is driven primarily by higher quality contractors being selected rather than by increased competition improving the quality of existing contractors.

\section{Conclusion}

This paper provides some of the first rigorous evidence on the impact of e-procurement on contractual choice and subsequent contract outcomes. All told, the results present a consistent story. E-procurement appears to have led to increased ability of firms from outside the home region to win contracts. These firms, in turn, tended to be higher quality firms in general, as measured by their average delay times (in Indonesia) and average quality (in India). This led to improvements in quality of roads and timeliness but no detectable changes in price.

Following the increase in competition among firms for contracts brought about by the adoption of e-procurement, a reduction in the rents accruing to winning firms may be expected to occur either through an increase in quality for a given price or a decrease in price for a given level of quality. In both the Indian and Indonesian settings examined here, we see evidence in support of improvements in quality for a given price. The fact that we observe changes on the quality margin, and that it occurs through changing which contractors win rather than the performance of a given set of winning contracts, suggests that the system prior to e-procurement was not necessarily selecting the most efficient firms, and that e-procurement may have improved efficiency even if it did not necessarily lower prices paid. It also suggests that the practice of giving contracts to the lowest price bidder likely contributed to greater inefficiencies on the quality margin.

Overall, our findings provide qualified support to the view that e-governance can improve governance. E-procurement was a partial reform which changed the application process but neither the rules for technical qualification nor the requirement that the lowest price bidder receive the contract. Case-study evidence suggests that official discretion in determining technical disqualification is often an important way of limiting competition. Equally, emphasizing price over quality (as occurs when lowest price bidder always wins) implies that bidders build in their profit margins by cutting back on quality. E-procurement facilitated entry but left significant discretion with officials in determining qualification and the bidding rules continued to prioritize low price over quality. 
Thus, it appears that the main impact we see can be attributed to gains from trade associated with having reduced barriers to entry. It is an open question whether a reform package which changes both the application process and also the process of selecting among bidders could lead to even larger gains in economic efficiency. 


\section{References}

[1] Aker, Jenny C. (2010). Information from Markets Near and Far: The Impact of Mobile Phones on Grain Markets in Niger. American Economic Journal: Applied Economics, $2(3): 46-59$.

[2] Aker, Jenny C., Christopher Ksoll, and Travis J. Lybbert (2012). Can Mobile Phones Improve Learning? Evidence from a Field Experiment in Niger. American Economic Journal: Applied Economics 4(4): 94-120.

[3] Asker, John (2010). A Study of the Internal Organization of a Bidding Cartel. American Economic Review, 100(3): 724-62.

[4] Auriol, E. (2006). Corruption in Procurement and Public Purchase. International Journal of Industrial Organization $24(5), 867-885$.

[5] Bandiera, O., A. Prat, and T. Valletti (2009). Active and Passive Waste in Government Spending: Evidence from a Policy Experiment. American Economic Review 99(4), 1278-1308.

[6] Briceño-Garmendia, C., A. Estache, and N. Shafik (2004). Infrastructure Services in Developing Countries: Access, Quality, Costs and Policy Reform. World Bank Policy Research Working Paper No. 3468.

[7] Bobonis, G., L.C. Fuertes, and R. Schwabe (2010). Does Exposing Corrupt Politicians Reduce Corruption? Unpublished paper, University of Toronto.

[8] Di Tella, Rafael \& E. Schargrodsky (2003). The Role of Wages and Auditing during a Crackdown on Corruption in the City of Buenos Aires. Journal of Law and Economics 46(1), 269-292.

[9] Ferraz, Claudio and F. Finan (2008). Exposing Corrupt Politicians: The Effect of Brazil's Publicly Released Audits on Electoral Outcomes. Quarterly Journal of Economics 123(2), 703-745.

[10] Freedom House (2012). Indonesia. Countries at the Crossroads, 2012 Edition. 
[11] Government of Indonesia. (2003). Presidential Decree Number 80 of 2003. Retrieved from http://bumn.go.id/data/uploads/files/1/80.pdf.

[12] Gruber, Jonathan H. and Sendhil Mullainathan (2005). Do Cigarette Taxes Make Smokers Happier. Advances in Economic Analysis and Policy, v5(1), Article 4.

[13] Indonesia Procurement Watch (2011). "Laporan Survei: Jejak Suap Dalam Pengadaan Barang/Jasa Pemerintah. Available at http://www.iprocwatch.org/berita/utama/173-hasilsurvei-ipw-qjejak-suap-dalampengadaan-barangjasa-pemerintahq.html.

[14] International Monetary Fund. International Financial Statistics. Washington, DC.

[15] Jensen, Robert (2007). The Digital Provide: Information (Technology), Market Performance and Welfare in the South Indian Fisheries Sector. Quarterly Journal of Economics 122(3), 879-924.

[16] Kenny, C. (2007). Construction, Corruption, and Developing Countries. World Bank Policy Research Working Paper No. 4271.

[17] Krasnokutskaya, E. and K. Seim (2006). Bid Preference Programs and Participation Highway Procurement Auctions. Working Paper, University of Pennsylvania.

[18] Olken, B. (2007). Monitoring Corruption: Evidence from a Field Experiment in Indonesia. The Journal of Political Economy 115(2), 200-249.

[19] Onishi, Norimitsu. (2009). "Corruption Fighters Rouse Resistance in Indonesia." The New York Times, July 26, 2009.

[20] Organisation for Economic Co-operation and Development. 2002. "The Size of Government Procurement Markets." OECD Journal on Budgeting 1(4), 8.

[21] Parlina, Ina. (2011). "Graft Cases Show Need for Procurement Law: Activists." The Jakarta Post, July 25, 2011. 
[22] Reinikka, R. and J. Svensson (2004). Local Capture: Evidence from a Central Government Transfer Program in Uganda. The Quarterly Journal of Economics 119(2), 678-704.

[23] Tran, A. (2008). Can Procurement Auctions Reduce Corruption? Evidence from the Internal Records of a Bribe-Paying Firm. Harvard Kennedy School job-market paper.

[24] United Nations Asia and Far East Institute (2008). Corruption Control in Public Procurement. Second Regional Seminar on Good Governance for Southeast Asian Countries.

[25] World Bank (2007). Electronic Government Procurement (e-GP): Opportunities and Challenges. World Bank Resources.

[26] World Bank and International Finance Corporation (2009). Enterprise Surveys: Indonesia Country Profile 2009. 


\begin{tabular}{|c|c|c|c|c|c|c|c|c|}
\hline & \multirow{2}{*}{\multicolumn{2}{|c|}{$\begin{array}{l}\text { India } \\
\text { All }\end{array}$}} & \multicolumn{6}{|c|}{ Indonesia } \\
\hline & & & \multicolumn{2}{|c|}{ All } & \multicolumn{2}{|c|}{ Works } & \multicolumn{2}{|c|}{ Consulting } \\
\hline & $\begin{array}{c}\text { Mean } \\
(\mathrm{SD})\end{array}$ & Obs. & $\begin{array}{c}\text { Mean } \\
(\mathrm{SD})\end{array}$ & Obs. & $\begin{array}{c}\text { Mean } \\
(\mathrm{SD})\end{array}$ & Obs. & $\begin{array}{c}\text { Mean } \\
(\mathrm{SD})\end{array}$ & Obs. \\
\hline \multicolumn{9}{|l|}{ State/Province-year level } \\
\hline Total projects & $\begin{array}{c}144.8 \\
(184.9)\end{array}$ & 158 & $\begin{array}{c}88.3 \\
(89.1)\end{array}$ & 166 & $\begin{array}{c}57.9 \\
(40.3)\end{array}$ & 164 & $\begin{array}{c}32.2 \\
(61.2)\end{array}$ & 160 \\
\hline Log total budget & $\begin{array}{c}9.610 \\
(1.469)\end{array}$ & 158 & $\begin{array}{l}25.674 \\
(0.944)\end{array}$ & 166 & $\begin{array}{l}25.610 \\
(0.918)\end{array}$ & 164 & $\begin{array}{l}22.886 \\
(1.156)\end{array}$ & 160 \\
\hline \multicolumn{9}{|l|}{ Package Level } \\
\hline Log estimated cost & $\begin{array}{c}5.211 \\
(0.846)\end{array}$ & 22378 & $\begin{array}{l}20.540 \\
(1.311)\end{array}$ & 14657 & $\begin{array}{l}20.952 \\
(1.350)\end{array}$ & 9502 & $\begin{array}{l}19.780 \\
(0.799)\end{array}$ & 5155 \\
\hline Contracts in package & $\begin{array}{c}1.251 \\
(1.088)\end{array}$ & 22378 & & & & & & \\
\hline $\begin{array}{l}\text { Log total value of contracts in } \\
\text { package }\end{array}$ & $\begin{array}{c}5.217 \\
(0.908)\end{array}$ & 22378 & & & & & & \\
\hline $\begin{array}{l}\text { Satisfactory quality at first } \\
\text { inspection }\end{array}$ & $\begin{array}{l}0.715 \\
(0.451)\end{array}$ & 11200 & & & & & & \\
\hline \multicolumn{9}{|l|}{ Contract level } \\
\hline Log contract value & $\begin{array}{c}4.529 \\
(2.044)\end{array}$ & 26654 & $\begin{array}{l}20.433 \\
(1.322)\end{array}$ & 14623 & $\begin{array}{l}20.826 \\
(1.381)\end{array}$ & 9491 & $\begin{array}{l}19.706 \\
(0.799)\end{array}$ & 5132 \\
\hline Log final payment & $\begin{array}{c}4.914 \\
(0.903)\end{array}$ & 14813 & & & & & & \\
\hline Completion delay (days) & $\begin{array}{c}244.3 \\
(345.4)\end{array}$ & 13781 & & & & & & \\
\hline Number of firms expressing interest & & & $\begin{array}{c}30.027 \\
(36.559)\end{array}$ & 14665 & $\begin{array}{c}35.104 \\
(43.389)\end{array}$ & 9508 & $\begin{array}{c}20.666 \\
(13.955)\end{array}$ & 5157 \\
\hline Number of firms bidding & $\begin{array}{c}2.756 \\
(3.075)\end{array}$ & 1628 & $\begin{array}{c}6.031 \\
(5.276)\end{array}$ & 14665 & $\begin{array}{l}7.586 \\
(5.904)\end{array}$ & 9508 & $\begin{array}{c}3.165 \\
(1.492)\end{array}$ & 5157 \\
\hline Time notice to award & & & $\begin{array}{c}98.513 \\
(105.286)\end{array}$ & 10410 & $\begin{array}{c}83.579 \\
(97.552)\end{array}$ & 6802 & $\begin{array}{l}126.668 \\
(113.281)\end{array}$ & 3608 \\
\hline Time bid open to award & & & $\begin{array}{c}29.066 \\
(17.648)\end{array}$ & 9194 & $\begin{array}{c}27.175 \\
(17.394)\end{array}$ & 5973 & $\begin{array}{c}32.572 \\
(17.581)\end{array}$ & 3221 \\
\hline Winner won in first year & $\begin{array}{c}0.109 \\
(0.312)\end{array}$ & 34126 & $\begin{array}{c}0.282 \\
(0.450)\end{array}$ & 9578 & $\begin{array}{c}0.212 \\
(0.408)\end{array}$ & 6896 & $\begin{array}{c}0.463 \\
(0.499)\end{array}$ & 2682 \\
\hline Winner from same district/prov. & $\begin{array}{c}0.302 \\
(0.459)\end{array}$ & 12871 & $\begin{array}{c}0.734 \\
(0.442)\end{array}$ & 6102 & $\begin{array}{c}0.817 \\
(0.387)\end{array}$ & 4152 & $\begin{array}{c}0.556 \\
(0.497)\end{array}$ & 1950 \\
\hline Time overrun ratio & $\begin{array}{c}2.262 \\
(3.018)\end{array}$ & 13628 & $\begin{array}{c}1.876 \\
(0.992)\end{array}$ & 4161 & $\begin{array}{c}2.179 \\
(0.991)\end{array}$ & 2986 & $\begin{array}{c}1.083 \\
(0.330)\end{array}$ & 1175 \\
\hline Late & $\begin{array}{c}0.766 \\
(0.423)\end{array}$ & 13628 & $\begin{array}{c}0.832 \\
(0.374)\end{array}$ & 4161 & $\begin{array}{c}0.948 \\
(0.223)\end{array}$ & 2986 & $\begin{array}{c}0.537 \\
(0.499)\end{array}$ & 1175 \\
\hline
\end{tabular}


Table 2: Budget Impact

\begin{tabular}{|c|c|c|}
\hline & \multicolumn{2}{|c|}{ State-year level } \\
\hline & (1) & (2) \\
\hline & $\begin{array}{c}\text { Log (total estimated } \\
\text { cost at state-year) }\end{array}$ & $\begin{array}{c}\text { Number of projects } \\
\text { in state-year }\end{array}$ \\
\hline \multicolumn{3}{|l|}{ Panel A: India } \\
\hline E-procurement & $\begin{array}{l}-0.041 \\
(0.089)\end{array}$ & $\begin{array}{l}-54.39 \\
(60.72)\end{array}$ \\
\hline Mean Dep. Var. (Non-Eproc) & $\begin{array}{c}9.55 \\
(1.41)\end{array}$ & $\begin{array}{c}139.20 \\
(184.07)\end{array}$ \\
\hline Obs. & 157 & 157 \\
\hline \multicolumn{3}{|c|}{ Panel B: Indonesia - Works Projects } \\
\hline E-procurement (IV) & $\begin{array}{c}0.187 \\
(0.151)\end{array}$ & $\begin{array}{l}-3.559 \\
(7.069)\end{array}$ \\
\hline Mean Dep. Var. (Non-Eproc) & $\begin{array}{l}25.211 \\
(0.774)\end{array}$ & $\begin{array}{c}45.102 \\
(28.803)\end{array}$ \\
\hline Obs. & 164 & 164 \\
\hline \multicolumn{3}{|c|}{ Panel C: Indonesia - Consultancy Projects } \\
\hline E-procurement (IV) & $\begin{array}{c}0.374 \\
(0.226)\end{array}$ & $\begin{array}{c}7.641 \\
(8.486)\end{array}$ \\
\hline Mean Dep. Var (Non-Eproc) & $\begin{array}{l}22.306 \\
(0.888)\end{array}$ & $\begin{array}{c}15.831 \\
(10.009)\end{array}$ \\
\hline Obs. & 160 & 160 \\
\hline \multicolumn{3}{|c|}{$\begin{array}{l}\text { India: Column (1) reports estimates from an OLS regression of log total estimated cost at the state- } \\
\text { year level on an indicator for any contract being awarded under e-procurement in the respective } \\
\text { state and year. Column (2) does the same using number of packages as the dependent variable. Log } \\
\text { of road length and log of estimated cost are included as controls when not on the LHS. }\end{array}$} \\
\hline \multicolumn{3}{|c|}{$\begin{array}{l}\text { Indonesia: Columns (1) and (2) give results from OLS regressions at the state-year level, where the } \\
\text { dependent variable is given in the table and the independent variable is the official adoption of } \\
\text { electronic procurement at the state level. Column (2) includes a control for log total state-year } \\
\text { estimated project cost. }\end{array}$} \\
\hline \multicolumn{3}{|c|}{$\begin{array}{l}\text { The state-year regressions include year fixed effects. Robust standard errors are in parentheses } \\
\text { below estimates. Means for each dependent variable are also reported, with standard deviations in } \\
\text { parentheses. }\end{array}$} \\
\hline
\end{tabular}




\begin{tabular}{|c|c|c|c|c|c|c|}
\hline & (1) & $(2)$ & (3) & (4) & (5) & (6) \\
\hline & $\begin{array}{c}\text { Time } \\
\text { elapsed } \\
\text { notice to } \\
\text { award }\end{array}$ & $\begin{array}{c}\text { Time } \\
\text { elapsed } \\
\text { bid open } \\
\text { to award }\end{array}$ & $\begin{array}{l}\text { Number } \\
\text { of firms } \\
\text { expressing } \\
\text { interest }\end{array}$ & $\begin{array}{l}\text { Number } \\
\text { of firms } \\
\text { bidding }\end{array}$ & $\begin{array}{c}\text { Winner } \\
\text { from same } \\
\text { province/ } \\
\text { district }\end{array}$ & $\begin{array}{c}\text { Winner } \\
\text { in first } \\
\text { year }\end{array}$ \\
\hline \multicolumn{7}{|l|}{ Panel A: India } \\
\hline \multirow[t]{2}{*}{ E-procurement } & & & & 0.364 & $-0.108 * * *$ & 0.0222 \\
\hline & & & & {$[0.733]$} & $(0.029)$ & $(0.0218)$ \\
\hline \multirow[t]{2}{*}{ Mean Dep. Var. (Non-Eproc) } & & & & 2.86 & 0.581 & 0.141 \\
\hline & & & & $(3.52)$ & $(0.493)$ & $(0.348)$ \\
\hline Obs. & & & & 1406 & 6545 & 26246 \\
\hline \multicolumn{7}{|c|}{ Panel B: Indonesia - Works Projects } \\
\hline \multirow[t]{2}{*}{ E-procurement (IV) } & 43.26 & 1.94 & $24.735^{*}$ & 0.420 & -0.036 & 0.070 \\
\hline & $(37.20)$ & $(5.40)$ & $(13.657)$ & $(1.520)$ & $(0.057)$ & $(0.060)$ \\
\hline \multirow[t]{2}{*}{ Mean Dep. Var. (Non-Eproc) } & 65.47 & 25.33 & 17.456 & 7.005 & 0.816 & 0.245 \\
\hline & $(74.45)$ & $(29.43)$ & $(21.460)$ & $(5.057)$ & $(0.387)$ & $(0.430)$ \\
\hline Obs. & 6798 & 5972 & 9323 & 9408 & 4151 & 6895 \\
\hline \multicolumn{7}{|c|}{ Panel C: Indonesia - Consultancy Projects } \\
\hline \multirow[t]{2}{*}{ E-procurement (IV) } & $54.13 * * *$ & 5.13 & -3.489 & -0.242 & $-0.233^{*}$ & $0.414^{* *}$ \\
\hline & $(19.81)$ & $(3.50)$ & $(2.561)$ & $(0.281)$ & $(0.133)$ & $(0.183)$ \\
\hline \multirow[t]{2}{*}{ Mean Dep. Var. (Non-Eproc) } & 98.14 & 26.13 & 11.069 & 3.178 & 0.650 & 0.446 \\
\hline & $(101.31)$ & (48.53) & (6.174) & (1.468) & $(0.477)$ & $(0.497)$ \\
\hline Obs. & 3607 & 3220 & 5078 & 5107 & 1944 & 2682 \\
\hline
\end{tabular}

India: All columns report OLS estimates from a regression at the contract level of the listed variable on an indicator for the contract being awarded using e-procurement. Column (4) is estimated on a subset of contracts for which we have bidding data in the states of Andhra Pradesh, Chhattisgarh, Karnataka, and Uttar Pradesh. Column (5) defines the district which a contractor is from as the mode district of the contractor's observed contracts prior to e-procurement starting anywhere in the country. This regression is therefore restricted to contracts won by the cohort of contractors who were awarded contracts prior to e-procurement. Winner in first year (Column (6)) is an indicator for the winner having been awarded a contract in 2000 or 2001 . This regression is restricted to observations after the first year. State and year fixed effects as well as controls for log of road length and log of estimated cost are included.

Indonesia: All columns report IV estimates at the project level, where the dependent variable is given in the table and the independent variable is the contract-level use of electronic procurement, instrumented by the official adoption of electronic procurement at the state level. Values of time elapsed in columns (1) and (2) were available for a subset of provinces in 2004 and all provinces in subsequent years. Column (5) defines the province where the contractor is from as the province as that directly indicated in the data. This regression therefore excludes contracts based out of the national headquarters. Column (6) defines winner in first year as an indicator for the winner having been awarded a contract in 2004. This regression is restricted to observations after the first year in the data. State and year fixed effects as well as a control for log of estimated cost are included.

Standard errors are clustered at the state level. Where brackets are used, p-values are given using the wild bootstrap method. None-procurement project means for each dependent variable are also reported, with standard deviations in parentheses.

*Significant at 10 percent. ${ }^{* *}$ Significant at 5 percent. ${ }^{* * *}$ Significant at 1 percent. 


\begin{tabular}{|c|c|c|c|c|c|c|c|c|}
\hline & $(1)$ & $(2)$ & (3) & $(4)$ & (5) & $(6)$ & (7) & $(8)$ \\
\hline & \multicolumn{2}{|c|}{ Prices } & \multicolumn{2}{|c|}{ Delays } & \multicolumn{4}{|c|}{ Quality } \\
\hline & $\begin{array}{c}\text { Log contract } \\
\text { value }\end{array}$ & $\begin{array}{l}\text { Log final } \\
\text { payment }\end{array}$ & $\begin{array}{c}\text { Late } \\
\text { completion }\end{array}$ & $\begin{array}{c}\text { Time } \\
\text { overrun } \\
\text { ratio }\end{array}$ & $\begin{array}{c}\text { First quality } \\
\text { grade }\end{array}$ & $\begin{array}{l}\text { First quality } \\
\text { grade (cond. } \\
\text { on completion) }\end{array}$ & $\begin{array}{l}\text { Minimum } \\
\text { across } \\
\text { quality } \\
\text { grades }\end{array}$ & $\begin{array}{c}\text { Minimum across } \\
\text { quality grades } \\
\text { (cond. on } \\
\text { completion) }\end{array}$ \\
\hline \multicolumn{9}{|l|}{ Panel A: India } \\
\hline \multirow[t]{2}{*}{ E-procurement } & 0.0184 & -0.0249 & 0.00116 & 0.127 & 0.0114 & $0.123 * *$ & 0.0442 & $0.194 * * *$ \\
\hline & $(0.0233)$ & $(0.0316)$ & $(0.0668)$ & $(0.233)$ & $(0.0279)$ & $(0.045)$ & $(0.0448)$ & $(0.033)$ \\
\hline \multirow[t]{2}{*}{ Mean Dep. Var. (Non-Eproc) } & 5.198 & 4.960 & 0.779 & 2.337 & 0.710 & 0.827 & 0.584 & 0.778 \\
\hline & $(0.843)$ & $(0.794)$ & $(0.415)$ & (3.117) & $(0.454)$ & $(0.378)$ & $(0.493)$ & $(0.416)$ \\
\hline Obs. & 20988 & 11237 & 13462 & 13462 & 11350 & 1783 & 11350 & 1783 \\
\hline \multicolumn{9}{|c|}{ Panel B: Indonesia - Works Projects } \\
\hline \multirow[t]{2}{*}{ E-procurement (IV) } & -0.049 & & $-0.161 *$ & 0.122 & & & & \\
\hline & $(0.047)$ & & $(0.089)$ & $(0.234)$ & & & & \\
\hline \multirow[t]{2}{*}{ Mean Dep. Var. (Non-Eproc) } & 20.766 & & 0.956 & 2.177 & & & & \\
\hline & $(1.329)$ & & $(0.204)$ & $(0.976)$ & & & & \\
\hline Obs. & 9485 & & 2985 & 2985 & & & & \\
\hline \multicolumn{9}{|c|}{ Panel C: Indonesia - Consultancy Projects } \\
\hline \multirow[t]{2}{*}{ E-procurement (IV) } & -0.023 & & 0.348 & 0.143 & & & & \\
\hline & $(0.022)$ & & $(0.231)$ & $(0.238)$ & & & & \\
\hline \multirow[t]{2}{*}{ Mean Dep. Var. (Non-Eproc) } & 19.502 & & 0.610 & 1.110 & & & & \\
\hline & $(0.841)$ & & $(0.488)$ & $(0.429)$ & & & & \\
\hline Obs. & 5130 & & 1175 & 1175 & & & & \\
\hline
\end{tabular}

India: Columns (1), (2), and (5)-(8) report OLS estimates from a regression at the package level of the listed variable on an indicator for any contract in the package being awarded under e-procurement. Columns (3) and (4) report OLS estimates from a regression at the contract level of the listed variable on an indicator for the contract being awarded using eprocurement. The regression in Column (1) is run on all packages for which one or more contract values were available. The values of multiple contracts in the same package were summed before taking the log. In Columns (2), final payment is the total amount paid out to contractors for work on the package, and the estimation sample consists of all packages for

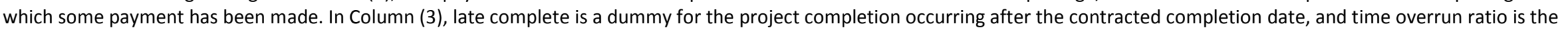
actual time to completion divided by the contracted time to completion. These two regressions are therefore run on all contracts for which both contracted and actual completion dates are listed. In Columns (5) and (6), the first quality grade is the earliest quality report (satisfactory [1] or unsatisfactory [0]) for any work done by any contractor working on the package. The minimum quality grade in Columns (7) and (8) is the lowest quality grade given at any time (across all contracts in the package). Columns (5) and (7) include all packages for which inspection data is available, while Columns (6) and (8) restrict to those packages which were complete when inspected. Column (5) also includes controls for complete at first inspection, first inspection year, and inspector. Column (6) includes controls for first inspection year and inspector. State and year fixed effects as well as controls for log road length and log estimated cost are included in all regressions.

Indonesia: All columns report IV estimates at the project level, where the dependent variable is given in the table and the independent variable is the contract-level use of electronic procurement, instrumented by the official adoption of electronic procurement at the state level. All regressions include state and year fixed effects and a control for log estimated project cost. The delay-related variables in columns (3) and (4) were constructed using follow-up data available for a subset of projects from the roads division.

Standard errors are clustered at the state level. Non-e-procurement project means for each dependent variable are also reported, with standard deviations in parentheses.

*Significant at 10 percent. ${ }^{* *}$ Significant at 5 percent. ***Significant at 1 percent. 


\begin{tabular}{|c|c|c|c|c|c|c|c|c|}
\hline & (1) & (2) & (3) & (4) & (5) & (6) & (7) & (8) \\
\hline & \multicolumn{2}{|c|}{ Prices } & \multicolumn{2}{|c|}{ Delays } & \multicolumn{4}{|c|}{ Quality } \\
\hline & $\begin{array}{l}\text { Log } \\
\text { contract } \\
\text { value }\end{array}$ & $\begin{array}{l}\text { Log final } \\
\text { payment }\end{array}$ & $\begin{array}{c}\text { Late } \\
\text { complete }\end{array}$ & $\begin{array}{l}\text { Time } \\
\text { overrun } \\
\text { ratio }\end{array}$ & $\begin{array}{l}\text { First } \\
\text { quality } \\
\text { grade }\end{array}$ & $\begin{array}{l}\text { First quality } \\
\text { grade } \\
\text { (cond. on } \\
\text { completion) }\end{array}$ & $\begin{array}{l}\text { Minimum } \\
\text { across } \\
\text { quality } \\
\text { grades }\end{array}$ & $\begin{array}{l}\text { Minimum across } \\
\text { quality grades } \\
\text { (cond. on } \\
\text { completion) }\end{array}$ \\
\hline \multicolumn{9}{|l|}{ Panel A: India } \\
\hline E-procurement & $\begin{array}{c}0.00206 \\
(0.01211)\end{array}$ & $\begin{array}{c}0.00568 \\
(0.01315)\end{array}$ & $\begin{array}{c}0.0119 \\
(0.0403)\end{array}$ & $\begin{array}{c}0.218 \\
(0.154)\end{array}$ & $\begin{array}{c}0.0214 \\
(0.0201)\end{array}$ & $\begin{array}{c}0.0973 * * \\
(0.0460)\end{array}$ & $\begin{array}{c}0.0181 \\
(0.0253)\end{array}$ & $\begin{array}{c}0.107^{* *} \\
(0.049)\end{array}$ \\
\hline Obs. & 18745 & 10161 & 9997 & 9997 & 9346 & 1789 & 9346 & 1789 \\
\hline \multicolumn{9}{|c|}{ Panel B: Indonesia - Works Projects } \\
\hline E-procurement (IV) & $\begin{array}{c}0.0642 \\
(0.0546)\end{array}$ & & $\begin{array}{c}-0.058 * * \\
(0.025)\end{array}$ & $\begin{array}{c}-0.127 \\
(0.138)\end{array}$ & & & & \\
\hline Obs. & 8352 & & 2941 & 2939 & & & & \\
\hline \multicolumn{9}{|c|}{ Panel C: Indonesia - Consultancy Projects } \\
\hline E-procurement (IV) & $\begin{array}{l}0.000007 \\
(0.00393)\end{array}$ & & $\begin{array}{c}-0.003 \\
(0.068)\end{array}$ & $\begin{array}{c}0.008 \\
(0.024)\end{array}$ & & & & \\
\hline Obs. & 4371 & & 948 & 955 & & & & \\
\hline
\end{tabular}

India: The first stage is an OLS estimate, where the dependent variable is given in the table and regressed on a set of winning-contractor fixed effects. The second stage regresses the estimated contract fixed effects for each contract on an indicator for the contract being awarded using e-procurement. Coefficients on the indicator from the second stage are reported. In the second stage, observations are analytically weighted by the inverse of the winning-contractor estimate squared standard errors. All regressions are run at the package level and are restricted to packages with one contract. State and year fixed effects as well as controls for log road length and log estimated cost are included in the second stage, while controls for e-procurement, log road length, and log estimated cost are included in the first stage.

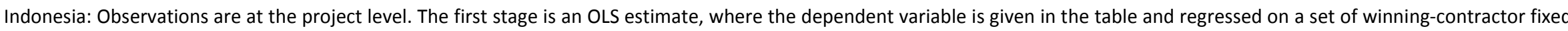

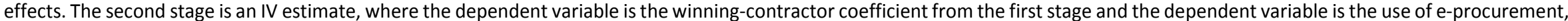

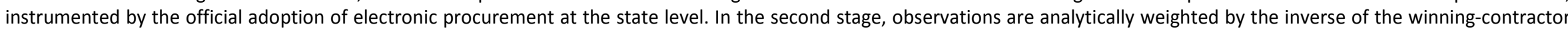

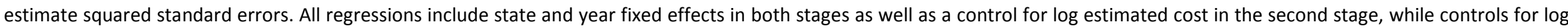
estimated cost, use of e-procurement at the project level, and adoption of electronic procurement at the state level are included in the first stage.

Standard errors are clustered at the state level. For descriptions of the dependent variables, see Table (4).

*Significant at 10 percent. ${ }^{* *}$ Significant at 5 percent. ${ }^{* * *}$ Significant at 1 percent. 
Appendix Table 1

\begin{tabular}{|c|c|}
\hline & State level \\
\hline & (1) \\
\hline & Difference in log contract value \\
\hline \multicolumn{2}{|l|}{ Panel A: India } \\
\hline \multirow[t]{2}{*}{ E-procurement } & 0.0130 \\
\hline & $(0.0378)$ \\
\hline \multirow[t]{2}{*}{ Mean Dep. Var. (Non-Eproc) } & 0.202 \\
\hline & $(0.697)$ \\
\hline Obs. & 24 \\
\hline \multicolumn{2}{|c|}{ Panel B: Indonesia - Works Projects } \\
\hline \multirow[t]{2}{*}{ E-procurement (IV) } & -0.084 \\
\hline & $(0.115)$ \\
\hline \multirow[t]{2}{*}{ Mean Dep. Var. (Non-Eproc) } & -0.039 \\
\hline & $(0.538)$ \\
\hline Obs. & 30 \\
\hline \multicolumn{2}{|c|}{ Panel C: Indonesia - Consultancy Projects } \\
\hline \multirow[t]{2}{*}{ E-procurement (IV) } & 0.017 \\
\hline & $(0.235)$ \\
\hline \multirow[t]{2}{*}{ Mean Dep. Var (Non-Eproc) } & -0.491 \\
\hline & $(0.725)$ \\
\hline Obs. & 28 \\
\hline
\end{tabular}

India: Column (1) reports an OLS estimate at the state level, where the dependent variable is the difference in log average contract value between 2000 and 2001. The independent variable is the year of official adoption of electronic procurement at the state level, conditional on adoption occurring after 2001.

Indonesia: Column (1) reports OLS estimates at the state level, where the dependent variable is the difference in log average contract value between 2005 and 2004. The independent variable is the year of official adoption of electronic procurement at the state level, conditional on adoption occurring after 2005.

The state-year regressions include year fixed effects. Robust standard errors are in parentheses below estimates. Non-e-procurement project means for each dependent variable are also reported, with standard deviations in parentheses.

*Significant at 10 percent. ${ }^{* *}$ Significant at 5 percent. ${ }^{* *}$ Significant at 1 percent. 
Figure 1: Number of Contracts by Number of Technical Disqualifications and Number of Bidders

\begin{tabular}{|c|c|c|c|c|c|}
\hline Number of & & & $f T$ & ific & \\
\hline Bidders & 0 & 1 & 2 & 3 & 4 \\
\hline 1 & 155 & & & & \\
\hline 2 & 4 & 15 & & & \\
\hline 3 & 1 & & 5 & & \\
\hline 4 & 3 & & & 4 & \\
\hline 5 & & & & & 1 \\
\hline Total & 163 & 15 & 5 & 4 & 1 \\
\hline
\end{tabular}


Figure 2a: E-procurement Adoption - India

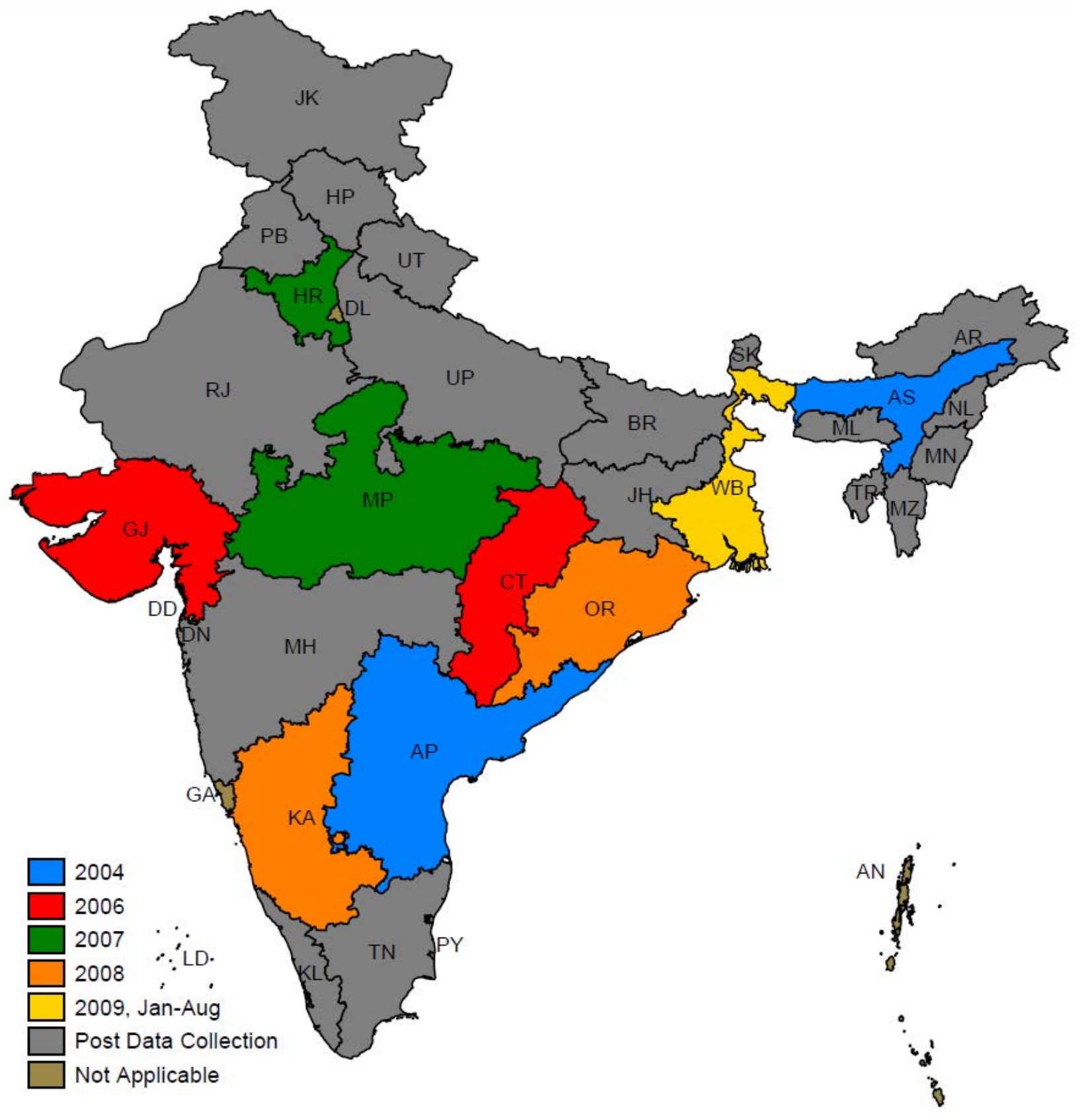


Figure 2b: E-procurement Adoption - Indonesia
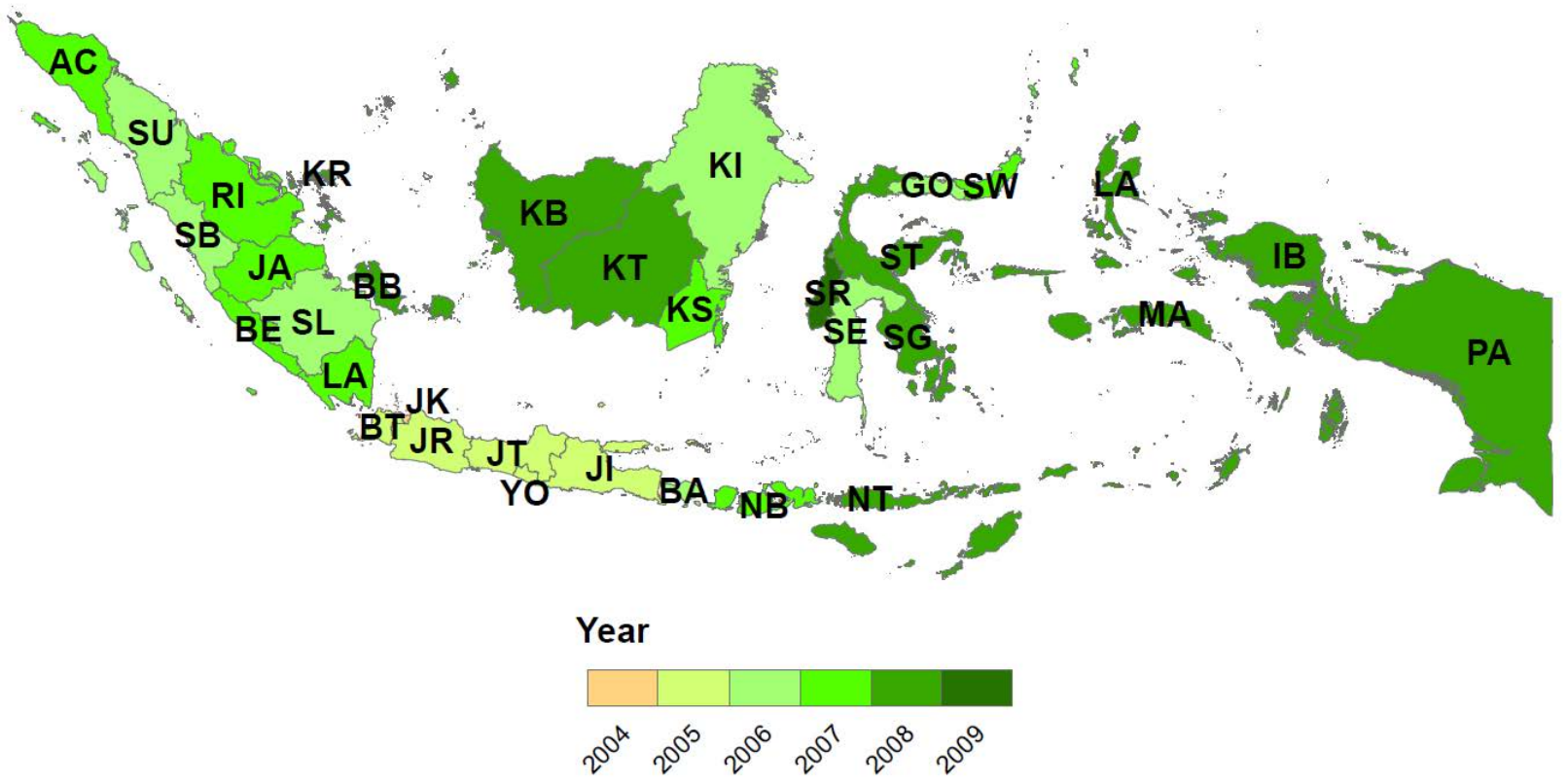